\title{
The Next Generation Can Help the Family Firm Innovate
}

Richard Schulze (Best Buy Inc)

Ritch Sorenson (University of St. Thomas)

KEYWORDS: Entrepreneurship, Management, Family

Business.

Much has been written about how family businesses can have transition problems when the founder's children take over. Best Buy founder Richard Schulze and Ritch Sorenson of the University of St. Thomas propose that the next generation plays a critical role in helping the enterprise build on its founder's strengths, engage more deeply with a new generation of customers and employees, and re-tool itself accordingly. The biggest challenge, as Schulze points out in this conversation, is convincing Mom and Dad that things need to change. 